\title{
First Names in a Social Context
}

\author{
Domagoj Vidović \\ Institute of Croatian Language and Linguistics, Zagreb, Croatia
}

\begin{abstract}
A B S T R A C T
In this paper, the influence of social change on the Croatian fond of first names is addressed. Once, first names served to indicate the belonging of an individual to a certain linguistic, religious or ethnic community; socio-political circumstances or affiliation with a place of origin were reflected in them, or they were a declaration of a certain social consciousness or political choice. From the second half of the 20th century onward, they have more often come to reflect individualization, and changes in the frequency of certain first names have become more evident. Male first names are more traditional and susceptible to the rules of inheritance, even though social circumstances are more strongly reflected in them, while female names are more open to more frequent change and to foreign linguistic systems.
\end{abstract}

Key words: first names, individualization, frequency of first names, first-name fond, linguistic systems

\section{Introduction}

Onyms are the oldest monuments of the Croatian language $^{1}$, and the first names of Croatian national rulers are both the first written traces of Croatian first names and the first written traces of Croatian distinctiveness. They are also a monument to the gradual integration of Croatian society into western European civilisation.

Up to the first half of the tenth century, Croatian national rulers (and Croatians in general) bore, almost exclusively, Croatian indigenous names, most often binomial, of which the majority contained the formant - mir 'great, renowned' (e.g., Branimir, Krešimir, Trpimir, Vojnomir), which crossed with the older formant *-mér 'world' (e.g., Gojmer, Putimer, Črnomer) or -slav 'renown' (e.g., Braslav, Miroslav, Radoslav, Tomislav, Višeslav, Zdeslav). First names originating from the names of animals also belong to the oldest stratum of Croatian indigenous names (e.g., Bivoj, Golub, Gujin, Grlica, Hlap, Rak, Vuk); the same true of names originating from flora (e.g., Bukva, Grab, Hrasto, Javor, Kaćunko, Loza) or professions (e.g., Kovač, Pop, Sedlar), but also of some other first names originating from nicknames, which today sound exotic (e.g., Besrama, Bezuh, Dosro, Grdan, Hrnjak, Klempo, Koljibaba, Krivošija, Nedostoja, Poruga, Preljub, Siromah, Sporko, Tupša, Ukraden, Vrag, Zloglas, Zlojutro, Zvjeronja) confirmed up to the end of the $15^{\text {th }}$ century, and, although rarely, even beyond that.

In the Middle Ages, however, the most common first names were those containing the anthroponymic base
Mil-/Mio- (e.g., Milislav, Miloš, Milovan, Miodrag), Rad(e.g., Radomir, Radoslav, Radovan) and Vuk- (e.g., Vučina, Vujana, Vuko). Among the first confirmed Croatian indigenous names are various first names containing the ethnonym Hrvat (e.g., Hrvoje, Hrvatin). They are confirmed to have existed during the Middle Ages on historical Croatian territory ranging from Bar, in what is now Montenegro, all the way to Istria, and from Podrinje to Medimur$\mathrm{je}^{2}$. Croatians, due to early contact with Christianity, began to already take on Christian names from the $9^{\text {th }}$ century onward; some of these were directly taken from Greek, or had Greek as a mediatory language (e.g., Ivan, Josip, Mihajlo/Mihovil, Tripun, Vlaho), and some originated in Greek, but were borrowed through Latin as a mediatory language (e.g., Barbara, Bazilije, Bartolomej, Blaž, Gabrijel). Christian names, such as Džore/Žuro 'Juraj', Menko 'Dominik', Vrsajko 'Ursus' or Zvan/Žan 'Ivan' entered into the Croatian language from Latin through the mediation of a Romance language (generally Dalmatian). Christian names only became dominant among Croatians in the $16^{\text {th }}$ century, after the Catholic Church instructed to clergymen that baptized individuals could only have Christian names. In Croatian territories, foreign names have also been confirmed, which began to gradually enter the Croatian first-name fond (e.g., Erik, Ferdinand, Žigmund), among which the first name Oliver stands out ${ }^{3}$, which spread substantially during the

Received for publication October 13, 2021 
mid-fourteenth century, especially in regions directly exposed to the Ottoman danger ${ }^{\mathrm{a}}$.

There are a few critical periods, after which changes in the frequency of certain Croatian first names intensified. When Croatian attained a kind of international recognition in the tenth century, Croatian rulers began to receive not only indigenous names, but Christian names as well (e.g., Mihajlo Krešimir, Stjepan Držislav), and, gradually, Christian names began to be used among the common people, first in cities, then in suburban surroundings, and much later in peripheral regions. Due to the regulations of the Council of Trent (1545-1563), Croatian indigenous names began to slowly disappear from use and their proportional use became smaller until the $19^{\text {th }}$ century, when they were somewhat revitalized due to the Croatian national revival. Political developments, however, greatly influenced changes in the frequency of use of certain first names in communist Yugoslavia. Thus, from 1945 until the 1970 s, the proportion of indigenous names in use began to slowly rise (some of which are also used by neighbouring South-Slavic peoples), with a subsequent lowering of the proportion of Christian names in use. After the Croatian Spring, as a kind of answer to the question of the suppression of Croatian national consciousness, the proportion of individuals named with 'state-building' names, such as Tomislav and Hrvoje (whose proportionate use grew even larger in the 1990s but began to fall again in the $21^{\text {st }}$ century), began to rise; traditional Christian names came to be in style again, and the use of foreign names grew as well, especially after the year 2000. In sum, various social changes have left their mark in Croatian first names over time, from the transition to Christianity through the strengthening of the influence of the Catholic Church and the strengthening of national consciousness, to secularization and globalization. Furthermore, the giving of first names, until recently, served to indicate the belonging of an individual to a certain religious community, ethnic group or native region, while today first names are more and more often a reflection of aspirations toward individuality.

In this work, there will be an attempt to demonstrate some of the changes mentioned through a breakdown of the changes in the fond of the most used first names based on the results of the Census of the Republic of Croatia.

\section{Male names}

According to the Census of the Republic of Croatia from 2011, the most common male names in the Croatian population are Ivan (130,828 individuals), Josip (77,323), Marko (50,393), Stjepan (45,287), Tomislav (39,105), Željko $(37,869)$, Ivica $(35,909)$, Ante $(35,457)$, Mario $(32,708)$

\footnotetext{
a The name Oliver was used by one of the characters of the Chanson de Roland (Song of Roland) from the 11th century, and this first name was first confirmed to be in use among the Romance-speaking population in Split and Zadar, and in the 14th century was in wide use in eastern Hercegovina and eastern Bosnia, as well as western Montenegro and Sanjak.
}

and Nikola (32,304). Therefore, the male inhabitants of the Republic of Croatia most often have the Christian first names Ivan, Josip, Marko, Stjepan, Ivica, Ante and Nikola, and somewhat more rarely the indigenous names Tomislav and Željko, while of foreign names the most common male first name is Mario, of Italian origin. Data from the National Bureau of Statistics on the frequency of certain names throughout the decades show that the proportion of usage of various first names changed. ${ }^{4}$

Thus, among residents of the Republic of Croatia born before 1929, most bore the first names Ivan, Josip, Stjepan, Franjo, Ante, Nikola, Petar, Milan, Dragutin and Marko. Among the most popular first names, thus, we find traditional Christian names, and those in a basic form at that (Ivan, Josip, Stjepan, Franjo, Ante, Nikola and Petar), with the proportion of bearers of the most common Croatian indigenous names (e.g., Milan and Dragutin) being four times lower. Until the period dating between 1960-1969, the first names Ivan, Josip and Stjepan were the three most common male names (with the first name Franjo being the fourth most common until 1950), the proportion of bearers of indigenous names gradually became larger (the names Branko, Vladimir, Željko, Damir, Darko, Zoran and Davor were more and more often given), and at the same time, the proportion of derivatives of Christian names rose (e.g., Ivica) which, before 1945, had been relatively smaller because the Catholic Church (which issued a portion of official documents) persisted in insisting that baptized individuals have first names based exclusively on basic forms (only the first names Ante and Mate in northern and central Dalmatia were much more common than their basic forms, Antun and Matej/Matija). During the period dating from 1960-1969, the indigenous name Željko became the most common male first name, and for the first and last time there were more indigenous names (Željko, Damir, Darko, Mladen, Zoran and Zlatko) than Christian (Ivan, Ivica, Josip and Stjepan) among the ten most popular male names. The reason behind the growth of the proportion of indigenous names is that they do not indicate an ethnic or religious orientation. During the period dating between 1970-1989, the proportion of people bearing the name Tomislav (under the influence of the Croatian Spring) and the ethnonymic name Hrvoje grew, first names which carried the strong emblem of nation-building. The proportion of indigenous names gradually fell (even though some indigenous names, such as Goran $^{5}$, which had been somewhat rare before, became more frequent), and for the first time some foreign names, such as the Italian name Mario, which was the most popular among boys born between 1979-1979 (other than Mario, with regard to foreign names the Russian name Igor and the French name Robert were common), made the top ten list of most frequent names ${ }^{\mathrm{b}}$. In the period dating between 1990-1999, the proportion of first names which had been borne by Croatian rulers (e.g., Domagoj, Krešimir,

\footnotetext{
b The first name Goran was already noted in Kotor in the 14th century, and 600 years later Ivan Goran Kovačić revitalized it with his nickname.
} 
Ljudevit and Borna) grew further, although none of them made the top ten list of most frequent names; new Christian (e.g., Filip and Matija) and foreign names (e.g., Antonio) appeared. Among newborn boys during the period dating between 2000-2011, the most common names were Luka, Ivan, Marko, Filip, Karlo, Josip, Antonio, David, Petar and Matej, altogether eight Christian names (of those which have been most commonly traditionally given, the names Ivan, Marko, Josip and Petar have survived; since 1990, the first name Filip has become more common, and the Christian name Luka has been the most common given in the $21^{\text {st }}$ century, even though during the $20^{\text {th }}$ century it was never among the most common in any single decade, while for the first time the Christian names David $^{5}$ and Matej entered among those most common) ${ }^{\mathrm{c}}$. Of foreign names during the transition from the $20^{\text {th }}$ to the $21^{\text {st }}$ century, the names Karlo and Antonio are most common, which are related to the Croatian traditional names Dragutin/Drago and Antun/Ante. From what is listed above, it is apparent that the proportion of Christian names from 1929 until today has changed the least. It should be noted, however, that the proportion of Christian names among the most common names fell to under 50\% only during the period dating between 1960-1979, and that the Christian names Stjepan, Franjo, Ante and Nikola became more rare (the first names Ivan, Marko, Josip and Petar are noted among the ten most common names up to 1929 , and again in the $21^{\text {st }}$ century), but the proportion of names originating from the Apostles (Filip, Matej and Matija ${ }^{\mathrm{d}}$ ) and from Old Testament saints (Danijel and David) grew. Among the most common first names for newborn boys in the $21^{\text {st }}$ century, there are no longer any bearers of indigenous names (even though six were noted among those born in the period dating between 1960-1969, and the most common name for newborn boys in that period was Željko). Foreign names began to be given more commonly from 1970 onward (in the period dating between 1970-1979 the most common name given was Mario), keeping in mind that the most common foreign names given after 1990 were Karlo and Antonio.

It must be emphasized that there are also certain differences in the giving of first names in the different regions of Croatia, which are conditioned by differences in history and custom. In the counties of Slavonia, the first names Mato and Đuro are far more common than in other regions, and the first name Ilija ${ }^{\mathrm{e}}$ is overrepresented (mainly among older individuals) in the counties of Brod-Posavina and Vukovar-Srijem ${ }^{6}$. In Osijek-Baranja County, the first names Zvonko (especially among middle-aged individuals) and Hrvoje (among those born between 1980-1989), in Požega-Slavonia County the first names Dalibor and Dario, and in Virovitica-Podravina County Saša, Slavko and Mirko are especially popular. On

\footnotetext{
${ }^{c}$ In older historical periods, the first name David was, regarding Croatian territories, commonly confirmed only in Boka Kotorska.

$\mathrm{d}$ The traditional names Matej, Matija, Mate and Mato have been supplanted more and more by the name Mateo, of Italian origin.

The first name Ilija is especially widespread among Bosnian Croatians, and it spread in Slavonia in good part due to immigration from Bosnia.
}

the other hand, eastern, central and northern regions of Croatia in the $21^{\text {st }}$ century are connected by the first name Mihael, which has almost completely superseded the traditional name Mijo.

In the north of Croatia, in all counties (Varaždin, Koprivnica-Križevac and Međimurje) the name Đuro is quite widespread, similar to the situation in Slavonia, and in the first decade of the $21^{\text {st }}$ century the first name Leon is particularly commonly given (especially in Varaždin County), which is also fairly widespread in part of central Croatia, in Istria, and on the Croatian littoral. In Varaždin County, however, among elder inhabitants the first name Vjekoslav is very common, while among younger inhabitants the names Patrik (which connects the region of Varaždin to parts of central Croatia) and Lovro (a first name that had earlier been much more common in the south of Croatia) are common. Medimurje County stands out from the other counties in the north of Croatian in that the first names Dejan, Denis and Kristijan are commonly given there. In Koprivnica-Križevac County, the name Siniša ${ }^{\mathrm{f}}$ is relatively common, a fact that it has in common with Bjelovar-Bilogora County, which is found in central Croatia $^{5}$.

Central Croatia is very diverse due to migratory movements. Thus, in Bjelovar-Bilogora County, the first names Dalibor and Saša are fairly common, as is the case in neighbouring Virovitica-Podravina County, as are Siniša, as in Koprivnica-Križevačka County, and Đuro, as in Slavonia and Baranja, and northern Croatia. Sisak-Moslavina County, Karlovac County, and Zagreb County are connected by that fact that elder inhabitants often have the first name Mijo, while Krapina-Zagorje County and Karlovac County are connected by the fact that the first name Kristijan was commonly given after 1990; Krapina-Zagorje, Sisak-Moslavina and Bjelovar-Bilogora counties are connected by the fact that the first name Patrik was commonly given after the year 2000. In Karlovac County, in comparison with the Croatian average, bearers of first name Mile (as in Lika and northern Dalmatia) are overrepresented, as are bearers of the first name Miroslav (generally among middle-aged inhabitants) and Dušan ${ }^{\mathrm{g}}$ (generally among members of the Serbian minority) in Sisak-Moslavina County ${ }^{7}$. In Zagreb County and Krapina-Zagorje County, among inhabitants born before 1929, bearers of the name Juraj are especially abundant, while older inhabitants of Zagorje often bear the name Rudolf. In Zagreb between the years 1970-1989, the name Hrvoje was often given, and in the $21^{\text {st }}$ century the revived name Fran stands out due to its frequency, which has generally superseded the traditional name Franjo.

\footnotetext{
${ }_{\mathrm{f}}^{\mathrm{f}}$ This first name spread due to the influence of the novel Grička Vještica (The Witch of Grič), written by Marija Jurić Zagorka.

${ }^{g}$ It must be noted that the names of Serbian rulers (along with the first name Dušan, the indigenous name Miloš was often given) were also fairly often given during the Croatian national revival in Dalmatia, as they were used to assert resistence to the Austro-Hungarian government and the imposing of the Italian language.
} 
In Lika, among Croats, the first names Mate, Jure and Joso are very common; among members of the Serbian minority, the name Dušan is common, while the name Mile is borne by both Croats and Serbs.

The first name Marin connects the northern and southern Adriatic. In the northern Adriatic, the first name Anton is especially common among elder inhabitants of the region, while among middle-aged inhabitants we find Goran and Boris, with Alen being common among younger inhabitants. In Istria County, foreign names such as Aldo, Bruno, Denis, Romano and Valter are very common, while in Primorje-Gorski Kotar County the indigenous names Nenad and Vedran are common. In all Dalmatian counties, the first name Ante is traditionally one of the most common, while after 1990 the Christian name Roko ${ }^{\mathrm{h}}$ became especially popular. The first name Mate is one of the most common in all Dalmatian counties, except for Dubrovnik-Neretva County, in which the form Mato is exclusively found east of the Neretva, as well as the forms Anto and Đure/Đuro, which tie that region to eastern Herzegovina, Bosnia and Slavonia. In Zadar County, Šime is one of the more common first names (of foreign names, as in Istria and Medimurje, the first name Denis is overrepresented), in Šibenik-Knin County Joso is one of the most common, in Split-Dalmatia County Duje is one of the most common, and in Dubrovnik-Neretva County Nikola and its various other forms (the most common being Niko and Nikša) and the shortened names Ivo and Pero are most common. It must be noted that the first name Tomislav was one of the most popular only in northern Dalmatia during the period 1930-1939, while in the rest of Croatia (apart from Lika, in which the first name Tomislav was one of the most common also during the period dating between 1960-1969) that name only began to be given more often after 1970. It is obvious that the celebration of the thousand-year anniversary of the coronation of King Tomislav $^{i}$ left a stronger trace in Dalmatia ${ }^{5}$, where there are practically no settlements in which there is not a memorial plaque with an inscription commemorating that anniversary ${ }^{\mathrm{j}}$.

From what has been written here so far, it is apparent that in Croatian there are certain historical (Croatian historical regions were, for centuries, divided up among different countries) and regional differences conditioned by local custom. In northern Croatian regions, for instance, the first name Ante is rare, while in the southern regions Franjo is rare; the first name Matija is almost exclusively a female name in the south, while in the north it is much more often a male name. Inhabitants of western

\footnotetext{
$\mathrm{h}$ The first name Roko became one of the most common first names due to inter-Croatian migrations.

Of Croatian indigenous first names after 2011, Borna is the indigenous name most often given, which is often also found as a woman's name. In 2011, there were 4329 male bearers of the name, and 114 female bearers living in Croatia

${ }^{\mathrm{j}}$ Generally, the names of Croatian rulers (except for the first name Zvonimir, and Krešimir to some extent) had already completely disappeared from use during the Middle Ages and were not revived until the 19 th century.
}

(chiefly Istrians), central and northern (chiefly inhabitants of Medimurje) Croatia much more often give foreign names that have entered the Croatian fond of first names in the last forty years or so, while Dalmatians, of all Croatians, are the most likely (even in the $21^{\text {st }}$ century) to give traditional names ${ }^{\mathrm{k}}$. The deep connection between very distant Croatian regions can be seen in the fact that the names Anto and Đuro are relatively often given both in Slavonia and in the region of Dubrovnik. These regions were, in fact, historically (through eastern Bosnia and eastern Herzegovina) much more closely linked, as also seen in some dialect features.

\section{Female names}

The most common names of female inhabitants of the Republic of Croatia, according to the 2011 census, are Marija (126,646 bearers of the name), Ana (81,751), Ivana $(49,943)$, Mirjana $(29,319)$, Katarina $(28,618)$, Nada $(26,660)$, Dragica $(25,952)$, Ljubica $(24,557)$, Vesna $(23,923)$ and Marina $(23,604)$. Thus, Croatian women most often bear the Christian names Marija, Ana, Ivana, Mirjana, Katarina and Marina, and the proportion of the female bearers of indigenous names (Nada, Dragica, Ljubica and Vesna) is twice that of their male counterparts. Based on this data, one might conclude that female names are even more traditional than male, but we will only be able to have a true insight into their evolution after retracing history. Namely, even during the Middle Ages, girls were given rare names such as Urozija or Eurozija in Žuljana on Pelješac, or Salabergia and Hermengilda in Kotor and Split, and later even some fairly rare names taken from prayerbooks (e.g., Apolonija or Skolastika).

Among the female inhabitants of the Republic of Croatia born before 1929, the most common first names were Marija, Ana, Kata, Milka, Dragica, Mara, Ljubica, Katarina, Danica and Anka. Therefore, Christian names were the most common among female names, although along with basic forms of the names (Marija, Ana and Katarina) shortened forms are also noted (Kata, derived from Katarina, and Mara, derived from Marija or, in southern Croatian regions, from Margareta) or derived forms (Anka from Ana), and among the more popular indigenous names we find some that are, for the most part, still fairly common today (Dragica, Ljubica and Danica), alongside the, today much more rare, first name Milka (the number of bearers of that name gradually grew smaller and after 1950 it was no long listed among the most common names).

The mentioned ratio between Christian and indigenous names did not change until 1950 when, likely due to the influence of political circumstances, the share of Christian names began to fall. This state lasted until 1979. In the period dating between 1950-1969, the indigenous names Nada and Vesna, and, to a lesser extent, Jadranka and Ljiljana, were extremely popular. During the period

\footnotetext{
${ }^{\mathrm{k}}$ Dalmatian cities are distinctive in that inhabitants are often named after local patron saints (cf. Donat, Duje, Stošija, Tripun, Vlaho).
} 
dating between 1960-1979, many Croatian women were given the relatively new indigenous names Snježana and Sanja. During the entire period dating from the beginning of the $20^{\text {th }}$ century and lasting until 1969 , the most common female name was Marija. After the Second World War, among the bearers of Christian names the number of women named Katica, Mirjana, Marica and Ivanka grew. The Christian name Ivana appears in 1970 among the most common names, and as the most common overall, at that, staying in first place until the year 2000. After 1970, the share of women bearing the first name Ana steadily rose, while after 1980 the same happened with those named Nikolina, after 1990 with Petra, Matea, Lucija (Lucija is also the first name most often given to girls in the $21^{\text {st }}$ century) and Sara (generally, Old Testament names were, until recently, relatively rare among Croatians), and after the year 2000 with Iva.

From 1960 onward, among the most common Croatian names we find foreign names, especially those which are formally similar to Croatian indigenous names, such as Gordana $^{1}$ (the name is especially common from 1960-1979; it is derived from the foreign name Gordijan, but folk etymology connects it to the adjective gord 'proud') ${ }^{5}$, Lana (it entered the fond of Croatian names both through Russian and through English, due to the popularity of the actress Lana Turner, and it is similar in sound to the noun lane) and Nika (even though the name is motivated by the name of the Greek goddess of victory, it is similar in sound to various versions of the name Nikolina). The female name Maja, on the other hand, originated with the same-sounding name of a Roman goddess of fertility (it is often also a hypocoristic of Marija), and the name Marijana, which was particularly commonly given between 1970-1979 (likely influenced by the hit by Dubrovački trubaduri of the same name) originated as a compound of the Christian names Marija and Ana. Even though they are derived from varieties of Christian names of varying origins, the first names Marina (St. Marin comes from Rab), Anita (a form of the first name Ana, which came to Croats through a Romance intermediary) and Ema (the Christian names Emilije and Emilija were confirmed at an early date, but the popularity of the first names Emil and Ema was definitely influenced by their popularity in Romance and Germanic languages).

In the $21^{\text {st }}$ century, the most prevalent first names among Croatian women have been Lucija, Ana, Lana, Petra, Sara, Ema, Marija, Nika, Ivana and Iva. From this, it is evident that from the period before 1929 until today only the names Ana and Marija have remained among the ten most common first names for Croatian women. Among the ten most common female names, eight are Christian (Lucija, Ana, Petra, Sara, Ema, Ivana and Iva) and two are foreign (Lana and Nika). Among the ten most common names there are no longer any indigenous names (the last indigenous name to make the list of the ten most common

\footnotetext{
${ }^{1}$ The popularity of the novel Gordana written by Marija Jurić Zagorka influenced the popularity of the name.
}

names was Snježana, which was the sixth most common female name in the period dating 1970-1979).

In various Croatian regions there are specific differences in the giving of female names conditioned by reasons pertaining to history and custom. Thus, in all Dalmatian counties except for Dubrovnik-Neretva County, the name Zorka, especially among Dalmatian women born before 1950 , is overrepresented in comparison to the rest of Croatia. The first names Sandra, Matija (Matija is most often a male name in northern Croatia), and Nina are overrepresented in central and southern Dalmatia, the first name Nevenka is overrepresented in central Dalmatian counties (Šibenik-Knin County and Split-Dalmatia County), and the first name Anđela and Marta are common among the female inhabitants of Zadar County and Šibenik-Knin County. Dubrovnik-Neretva County stands out by way of the large representation of the regional names Ane, Kate, Jele and Mare, as well as by the frequent giving of the first name Andrea. Older female inhabitants of Split-Dalmatia County (especially in the hinterland) often have the first name Anda, with the youngest often having the name Mia. Older female inhabitants of Šibenik-Knin County, on the other hand, often have the first name Stana, while Zadar County stands out due to the overrepresentation of the first name Ika. The Adriatic coast, from Savudrija to Prevlaka, is connected in its entirety through the frequency of the giving of the female name Sandra in generations born between 1970-1979 and the first name Mia among the youngest female inhabitants of the region. Primorje-Gorski Kotar County and Istria County have the giving of the first name Nataša in common. Istria, as expected, differs from the Croatian average. In it, some regional names of Romance origin are represented, such as Fuma $\left(<\right.$ Eufemija $\left.^{\mathrm{m}}\right)$ and Albina, the name Maria, unadapted to orthographic norms, as well as some less "exotic" names which are not among the most common in Croatia, such as Tatjana and Tea ${ }^{5}$. Istria is linked with Međimurje through the common giving of the personal names Lidija and Suzana, it is linked with continental Croatia in general through the giving of the first name Barbara, with Lika through the many female bearers of the name Zora, and with northern Dalmatia through the common giving of the first name Anđela (although the first name Anđela has long taken root in Istria, while in Dalmatia it served to make the name Anđa "more young"). Primorje-Gorski Kotar County (and Dubrovnik-Neretva County) stand out due to the many female bearers of the name Andrea.

In Lika, alongside the already mentioned indigenous name Zora, which is also commonly given in Istria, the Christian name Manda is overrepresented, and is also borne by many Slavonian women and female inhabitants of Šibenik-Knin County.

The situation in central Croatia is quite varied. Among younger female inhabitants of the region, the first name

\footnotetext{
m This Christian name was prevalent during Medieval times along the entire coast of the Adriatic Sea, and the first historical records of this name date from the 11th century, when the Christian name Eufemia was confirmed in Trogir.
} 
Valentina is especially common (the name is overrepresented in Istria, north-western Croatia and in Slavonia), as is Lorena (the name is very common in the remaining lowland region of Croatia). Bjelovar-Bilogora County and Virovitica-Podravina County stand out due to the frequency of the name Zdenka. The latter county is also noted for the female name Jana, which isn't otherwise commonly given anywhere else in Croatia, as well as for the frequency of the first name Terezija, relating it to western Slavonia and the north of Croatia, as well as the frequency of the name Ruža, a trait that it shares with all the counties of Slavonia, except for Požega-Slavonia County. Karlovac County stands out because it is the only one in which the shortened name Bara (< Barbara) is very common, as is the name Dora which, aside from the region of Karlovac, is most common in Međimurje and Zagreb. In Sisak-Moslavina County the situation is roughly in keeping with the Croatian average. Zagreb County and Krapina-Zagorje County are connected with Koprivnica-Križevac County by way of the first name Barica, with Varaždin County by the first name Štefica, and Varaždin County, Koprivnica-Križevac County, Zagreb County and Istria County are connected by way of the first name Barbara. Zagreb County and Krapina-Zagorje County, as well as the city of Zagreb, have in common the fact that there are many women bearing the name Renata in each. Krapina-Zagorje County stands out due to the overrepresentation of the first names Štefanija (something it has in common with Međimurje County), Ivka (which it has in common with Varaždin County), and Biserka (which it has in common with both Varaždin and Međimurje County). The city of Zagreb, on the other hand, is connected to Adriatic counties by way of the many bearers of the first name Sandra.

The situation in the north of Croatia is very similar to that of counties in the central portion of Croatia: among older female inhabitants, the names Štefica and Barica are very common, among middle-class women the name Biserka is very common, and young women are very frequently named Valentina or Lorena. Generally, in Podravina the first name Terezija is overrepresented. Varaždin County stands out due the frequency with which woman are named Marta (a trait it shares with Požega-Slavonia County and northern Dalmatian counties). Međimurje County and Varaždin County have the name Nevenka in common (a trait which they share with central Dalmatian counties). Koprivnica-Križevac County differs from the rest of Croatia by way of the fact many women there bear the name Đurdica. Medimurje is the most unusual county in the north of Croatia by way of the fact that, other than the already mentioned names that it has in common with other counties, there are many women named Rozalija, Elizabeta, Julijana, Franciska and Veronika, and, along with Dubrovnik-Neretva County and Istria County, deviates the most from the Croatian average.

In the counties of Slavonia, the names Manda and Ruža (except in Osijek-Baranja County) are overrepresented among older women, while among younger women the same of true of the name Valentina (except in Vukovar-Sri- jem County). The western counties of Slavonia are like those of Podravina due to the significant representation of the first names Terezija and Slavica (the first name Slavica is also common in Istrija), the southern counties are allied with some of the counties of central Croatia according to the frequency of the first name Željka, while the eastern counties stand out due to the frequency of the first name Ružica (which is also fairly common in Varaždin County). In Vukovar-Srijem County bearers of the names Biljana (which is a fairly recent name to appear, whose entry into the Croatian fond of first names is tied to the popularity of the Macedonian folk song Biljana platno beleše) stand out due to their frequency in comparison with the rest of Croatia.

In the fond of female names, there are more many changes than in the fond of male names. Thus, in the 1960s, the previously popular female names Ljubica, Dragica, Milka and Marica vanished from the list of ten most popular names and were replaced by, among others, the female names Snježana, Gordana and Ljiljana, which kept their place among the most popular names for the next twenty years or so. In the $21^{\text {st }}$ century, foreign (usually short) names and Christian names which were borrowed through Romance or German languages have become much more common. Female names have been less subject to the influence of politics (it is only in the case of the frequency with which women are given names of Russian origin such as Nataša or Tatjana in Istria or on the Croatian coast, or in the popularity of the name Jelena, borne by a Croatian ruler, the $1000^{\text {th }}$ anniversary of whose death the Catholic Church used in 1976 to awaken Croatian national consciousness, that names can be seen as a reflection of political circumstance), and much more subject to global trends. Three counties stand out from the Croatian average: Međimurje (where there are many bearers of the first names Rozalija, Elizabeta, Julijana and Franciska), Istria (by way of female names of Romance origin, such as Fuma and Albina, and by the name Maria, which is unadapted to Croatian orthography) and Dubrovnik-Neretva (by way of the regional names Ane, Kate, Jele and Mare).

\section{Conclusion}

First names are not only a part of anthroponymic formulas, they are also the first Croatian linguistic monuments, in which social change has been reflected for centuries. Once, they had shown belonging to a certain linguistic, religious or ethnic community, and in them socio-political circumstances were mirrored (thus, in Dalmatia in the $19^{\text {th }}$ century, Italian names were more common among Autonomists, while indigenous names were more common among members of the People's party or affiliation with their native land (this mainly refers to popular saints, such as Saint Eufemija in Istria or Duje, Stošija, Tripun and Vlaho in Dalmatia), or they were a declaration of a certain social consciousness or political choice. From the second half of the $20^{\text {th }}$ century, they be- 
come more often a way to express individuality. Centuries were needed for a deep-rooted change to take hold in the fond of Croatian first names in the Middle Ages (the gradual entry of Christian names into the Croatian first name fond began with the conversion to Christianity, yet Christian names did not become dominant until the late Middle Ages; from the $19^{\text {th }}$ century until the middle of the $20^{\text {th }}$ century, the first names of Croatian national rulers are, for the first time, revived, their pronounced return into fashion happening during the Croatian Spring), and from the beginning of the $21^{\text {st }}$ century, changes in the fond of first names occur ever faster due to the influence of glo- balization, but they are not yet very evident on a general level for demographic reasons (the natality rate is three times less what it was after the Second World War). Male first names are more traditional and more subject to rules of inheritance, even though social circumstances are more strongly reflected (cf. the more common giving of the first names Tomislav and Hrvoje shortly before and after the Croatian spring), and female names are more open to more frequent changes and foreign linguistic systems. Whether or not these same trends will continue in the future will already be seen in the results of the Croatian census of 2021.

\section{R E F E R E N C E S}

1. ŠIMUNOVIĆ P, Uvod u hrvatsko imenoslovlje (Golden MarketingTehnička knjiga, Zagreb, 2009) 11. - 2. VIDOVIĆ D, Osobna imena u Dubrovniku i njegovu okružju u kasnome srednjovjekovlju. In: GRČEVIĆ M, VEKARIĆ N (Eds): Dubrovnik u hrvatskoj povijesti. Zbornik u čast Nenadu Vekariću (Hrvatski studiji Sveučilišta u Zagrebu, Zagreb, 2019). - 3. JIREČEK K, Romani u gradovima Dalmacije tokom srednjeg veka. In: DINIĆ M (Ed): Zbornik Konstantina Jirečeka 2 (Naučno delo, Beograd, 1962). — 4. CROATIAN BUREAU
OF STATISTICS, Most frequent male and female names by year of birth, by counties, census 2011, https:/www.dzs.hr/eng/censuses/census2011/results/censustabsxls.htm. - 5. ČILAŠ ŠIMPRAGA I, IVŠIĆ MAJIĆ D, VIDOVIĆ D, Rječnik suvremenih hrvatskih osobnim imena (Institut za hrvatski jezik i jezikoslovlje, Zagreb, 2018). - 6. VIDOVIĆ D, Folia onomastica Croatica, 25 (2016) 175. doi: https://doi. org/10.21857/9e31lh45jm. - 7. ROGOŠIĆ A, Folia onomastica Croatica, 25 (2016) 154. doi: doi.org/10.21857/90836cd5ly.

\section{Vidović}

Institute of Croatian Language and Linguistics, Ulica Republike Austrije 16, 10000 Zagreb, Croatia

e-mail:dvidovic@ihjj.hr

\section{OSOBNA IMENA U DRUŠTVENOME KONTEKSTU}

\section{S A Ž E T A K}

U ovome se radu naznačuje utjecaj društvenih promjena na hrvatski osobnoimenski fond. Nekoć se osobnim imenima iskazivala pripadnost određenoj jezičnoj, vjerskoj ili etničkoj zajednici, u njima su se odražavale društveno-političke okolnosti ili pripadnost zavičaju, odnosno bila su iskazom određene društvene svijesti ili političkoga odabira. Od druge polovice XX. stoljeća ona su sve češće odrazom individualizacije te su promjene u čestoći pojedinih osobnih imena sve vidljivije. Muška su osobna imena tradicionalnija i podložnija pravilima nasljeđivanja iako se u njima snažnije odražavaju društvene okolnosti, a ženska otvorenija češćim promjenama i stranim jezičnim sustavima. 
